原著

\title{
Flow cytometric trials to detect tumor cells expressing tumor marker gp 160 in pleural fluids and ascites
}

\author{
Kazuo Kato ${ }^{1)}$, M.D., F.I.A.C., Naoki Yoshimi ${ }^{1)}$, M.D., M.I.A.C., \\ Shigetoyo Saji ${ }^{2}$, M.D., Hiroto Shima ${ }^{1)}$, M.D., Shigeyuki Sugie ${ }^{1)}$, \\ M.D., M.I.A.C., Takuji Tanaka'), M.D., F.I.A.C., \\ and Masayoshi Takahashi ${ }^{3)}$, M.D., F.I.A.C. \\ ${ }^{1)}$ Department of Pathology and ${ }^{2)}$ Department of Surgery, \\ Gifu University School of Medicine, Gifu, 500, Japan \\ ${ }^{3)}$ Tokyo Special Reference Laboratory, Hachioji, Tokyo, 192, Japan
}

\begin{abstract}
Expression of tumor-associated antigen gp 160 in 23 specimens of body fluids was analyzed by flow cytometry with the use of a monoclonal antibody $5 \mathrm{E} 8$. Lymphocytes (the negative control) had a mode fluorescence intensity of channel 10 ; $95 \%$ of the cells consistently fell below channel 40 . Cells with fluorescence intensity below channel 40 were designated as gp 160 negative and all cells with fluorescence intensity above channel 40 were designated as gp 160 positive. Cultured cells derived from a lung large cell carcinoma, C-1509 (the positive control) had an adjusted mode fluorescence intensity of channel 60 ; the rate of gp 160 positive cells was $81.7 \%$. All cytologically malignant specimens from patients with lung cancer and stomach cancer showed more than 50\% gp 160 positive cells and a wide fluorescence distribution pattern $(8 / 8)$. It may be useful to detect lung cancer or stomach cancer cells in body fluids by flow cytometry with the monoclonal antibody $5 \mathrm{E} 8$.
\end{abstract}

Key words : Body fluid-Glycoprotein-Tumor-associated antigen-Monoclonal antibody_-Flow cytometry

Correspondence to K. Kato, Department of Pathology, Gifu University School of Medicine, Tukasamachi, Gifu, 500, Japan

胸腹水中の腫瘍マーカー gp 160 陽性腫瘍細胞のフローサイト

メトリによる検出

加藤一夫 ${ }^{1}$, 吉見直己 ${ }^{1)}$, 佐治重豊 ${ }^{2}$, 島 寛人 ${ }^{1)}$, 杉江茂 幸1), 田中卓二 ${ }^{11}$, 高橋正宜 ${ }^{3)}$

1)岐皁大学医学部病理学第 $1,{ }^{2}$ 同 外科学第 2

${ }^{3}$ SRL 八王子研究所

論文別刷請求先 -500 岐阜市司町 40 岐阜大学医学部病理 学第 1 加藤一夫

\section{Introduction}

Flow cytometric methodology represents a powerful analytical tool for screening and detecting abnormal and malignant cells, for 
Table 1 A Channel of peak cell count after immunofluorescence reaction with the monoclonal antibody $5 \mathrm{E} 8$; percentage of gp 160 positive cells in pleural fluid specimens, estimated by flow cytometry

\begin{tabular}{cccccc}
\hline \hline Case & $\begin{array}{c}\text { Clinical } \\
\text { diagnosis }\end{array}$ & $\begin{array}{c}\text { Papanicolaou's } \\
\text { cytological } \\
\text { classification }\end{array}$ & $\begin{array}{c}\text { Peak } \\
\text { channel }\end{array}$ & $\begin{array}{c}\text { Distribution } \\
\text { pattern of } \\
\text { fluorescence }\end{array}$ & $\begin{array}{c}\% \text { of gp } 160 \\
\text { positive } \\
\text { cells }\end{array}$ \\
\hline 1 & Lung cancer & 5 & 120 & Wide & 98.6 \\
2 & Lung cencer & 5 & 60 & Wide & 84.1 \\
3 & Lung cencer & 5 & 40 & Wide & 78.5 \\
4 & Lung cancer & 5 & 40 & Wide & 61.4 \\
5 & Lung cancer & 5 & 40 & Wide & 54.2 \\
6 & Lung cancer & 2 & 20 & Gaussian & 42.7 \\
7 & Lung cancer & 2 & 30 & Gaussian & 35.1 \\
8 & Lung cancer & 2 & 10 & Gaussian & 2.7 \\
$9^{\text {a }}$ & Tuberculosis & 2 & 40 & Gaussian & 45.9 \\
$10^{\text {b }}$ & Lymphocytes & & 10 & Gaussian & 1.5 \\
$11^{\text {c }}$ & C-1509 & & 60 & Gaussian & 81.7 \\
\hline
\end{tabular}

a : Pericardial fluid, b: negative control, c: positive control

Table 1 B Channel of peak cell count after immunofluorescence reaction with the monoclonal antibody $5 \mathrm{E} 8$; percentage of gp 160 positive cells in ascites specimens, estimated by flow cytometry

\begin{tabular}{cccccc}
\hline \hline Case & $\begin{array}{c}\text { Clinical } \\
\text { diagnosis }\end{array}$ & $\begin{array}{c}\text { Papanicolaou's } \\
\text { cytological } \\
\text { classification }\end{array}$ & $\begin{array}{c}\text { Peak } \\
\text { channel }\end{array}$ & $\begin{array}{c}\text { Distribution } \\
\text { pattern of } \\
\text { fluorescence }\end{array}$ & $\begin{array}{c}\% \text { of gp 160 } \\
\text { positive } \\
\text { cells }\end{array}$ \\
\hline 12 & Stomach cancer & 5 & 80 & Wide & 92.5 \\
13 & Stomach cancer & 5 & 30,80 & Wide & 57.7 \\
14 & Stomach cancer & 5 & 30,65 & Wide & 53.5 \\
15 & Stomach cancer & 1 & 10 & Gaussian & 17.4 \\
16 & Breast cancer & 5 & 30 & Gaussian & 24.8 \\
17 & Hepatoma & 5 & 20 & Gaussian & 35.1 \\
18 & Hepatoma & 1 & 25 & Gaussian & 30.7 \\
19 & Hepatoma & 1 & 10 & Gaussian & 5.0 \\
20 & Pancreas cancer & 5 & 10 & Gaussian & 33.2 \\
21 & Pancreas cancer & 4 & 20 & Gaussian & 27.3 \\
22 & Renal cancer & 1 & 10 & Gaussian & 1.3 \\
23 & Mixed Müllerian tumor & 3 & 30,80 & Wide & 60.4 \\
24 & Ovarian cancer & 5 & 40 & Wide & 82.4 \\
25 & Ovarian cancer & 5 & 15 & Gaussian & 6.3 \\
\hline
\end{tabular}

subclassifying malignancies beyond conventional morphologic type and grade, and for transcending light-microscope features by providing more biologically meaningful information. Flow cytometric tecniques for analyzing DNA content and elevated tumor proliferation activity are now widely used ${ }^{1)}$. Although flow cytometry is considered to be a potential tool for measuring and detecting tumor-associated markers, only a few studies have been reported $^{2 \sim 5)}$. In order to apply the flow cytometric method to screening for malignant cells, it is essential to find appropriate tumor associated markers which are useful for flow cytometry.

The monoclonal antibody $5 \mathrm{E} 8$, originally raised against a lung epidermoid carcinoma cell line ${ }^{6}$, has been shown to react with malignant 
cells of other primary tumors including those arising in the colon, stomach and breast. This antibody recognizes an epitope contained within a 160,000 dalton non-disulfide-bonded glycoprotein ${ }^{7,8)}$. This molecule, dubbed gp 160, was identified on a broad spectrum of human lung tumors but was undetectable on normal human lung tissue. Because gp 160 has been identified as a plasma membrane-associated glycoprotein, it holds promise as a detector of relatively free tumor cells in pleural fluids or ascites in conjunction with flow cytometry. This paper reports on our investigation of this possibility.

\section{Materials and methods}

\section{Histological/clinical assessment}

The samples studied were obtained from fresh body cavity fluids submitted for conventional diagnostic cytology. A total of 23 samples of body cavity fluids from unselected patients were analyzed by conventional cytopathology and flow cytometry.

The fluid specimens were applied to slides and processed for conventional cytological assessment. The specimens, to be used for gp 160 testing, were fixed in formol saline for the examination of $\mathrm{gp} 160$. The cytological specimens were classified on the basis of cytological diagnosis in the context of clinical presentation.

\section{Monoclonal Antibodies}

The hybridoma secreting monoclonal antibody specific for gp 160 was produced $^{6)}$. Hybridoma cells were propagated in vivo in peristane-treated BALB/c mice. Ascites fluid was harvested and precipitated by half-saturated ammonium sulfate. The $\gamma$-globulin precipitates were dissolved in borate-buffered saline ( $\mathrm{pH} 8$ ), and after extensive dialysis the mouse immunoglobulin was bound to an affinity col- umn containing rabbit anti-mouse $\gamma 1$-specific antibodies coupled to Sepharose $4 \mathrm{~B}$. The mouse immunoglobulin was eluted from the column with $0.2 \mathrm{M}$ glycine- $\mathrm{HCl}, \mathrm{pH} 2.8$. The antibody was stored at $-20^{\circ} \mathrm{C}$ after extensive dialysis.

\section{Immunocytochemical staining}

The cells of each body fluid were fixed in formol saline and stored at $4^{\circ} \mathrm{C}$ until they could be stained. Prior to staining, the fixed cells were washed twice with $0.01 \mathrm{M}$ phosphate buffered saline, $\mathrm{pH} 7.2$ (PBS), and then treated with PBS supplemented with $1 \%$ swine serum for 30 minutes. After being washed, the cells were incubated with monoclonal antibody $5 \mathrm{E} 8$ for 30 minutes, washed twice with PBS, and then incubated with fluorescent isothiocianate (FITC)-conjugated swine anti-mouse immunoglobulin (DAKO Immunoglobulins A/S Copenhagen, Denmark) at room temperature for 30 minutes.

Cell line C-1509, which was derived from a human lung large cell carcinoma, was used as a positive control and lymphocytes from normal human blood as a negative control.

\section{Flow cytometry analysis}

The suspension was filtered through $40 \mu \mathrm{m}$ pore size nylon mesh to remove large clumps before analysis. An Ortho $50 \mathrm{H}$ flow cytometer (Ortho Diagnostic Systems, Westwood, Massachusetts) linked to an Ortho Model 2150 digital computer was used for analysis. The excitation wave length of the argon ion laser (Spectra-Physics 164-03) was $488 \mathrm{~nm}$ with a $500 \mathrm{mw}$ output. Emissions were measured at $530-570 \mathrm{~nm}$ by using a band-pass filter. The flow cytometer was standardized using $2.00 \mu \mathrm{m}$ Lactec particles (Polyscience, Warrington, Pennsylvania). The samples stained with $5 \mathrm{E} 8$ were analyzed on the green fluorescence channel using logarithmic amplification.

Gates were set on the forward and right- 

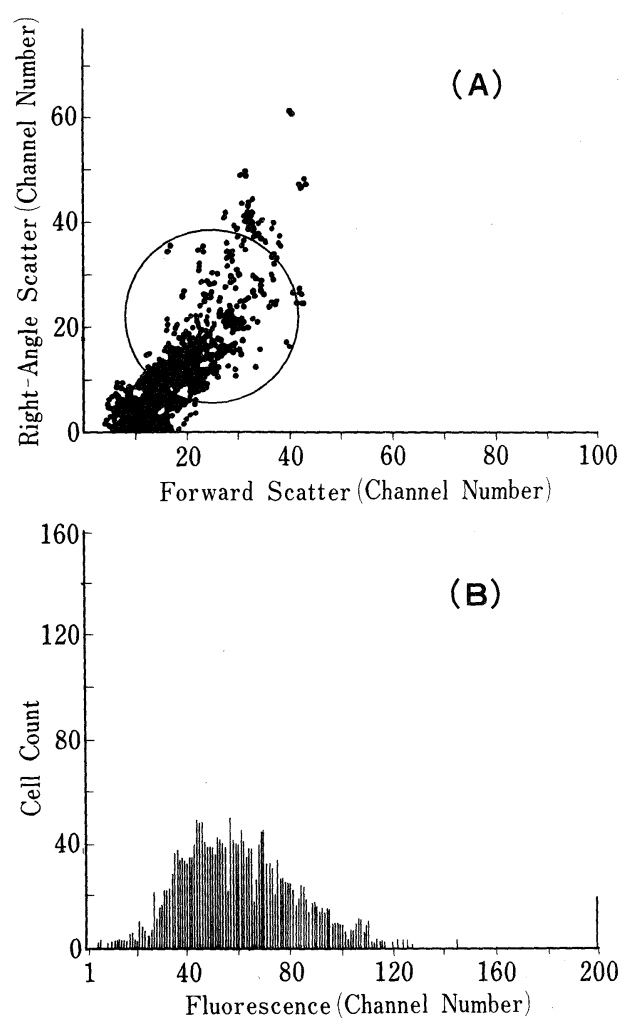

Fig. 1 Flow cytometry of cultured cells C-1509 as a positive control. The $\mathrm{X}$-axis represents forward light scatter and the $\mathrm{Y}$-axis $90^{\circ}$ scatter (A). Fluorescence intensity of cells that reacted with $5 \mathrm{E} 8$ (circled in A) (B)

angle light scatter to exclude debris, erythrocytes and clumps (Fig. $1 \mathrm{~A}$ ) and the percentage of antibody-bound cells was determined from a fluorescence histogram (Fig. $1 \mathrm{~B}$ ).

\section{Results}

Intense fluorescence was observed in pleural fluids with lung cancer cells (Fig. $2 \mathrm{~A}$ and $2 \mathrm{~B}$ ), and in ascites with stomach cancer cells after staining with the monoclonal antibody $5 \mathrm{E} 8$.

Lymphocytes, the negative control, had a mode fluorescence intensity of channel 10 ; $95 \%$ of the cells consistently fell below channel 40 and many were below channel 20. Because of this, cells with fluorescence intensity weaker than channel 40 were designated as gp 160 negative and cells with fluorescence at any value above channel 40 were regarded as gp 160 positive. The C-1509 cultured tumor cells, the positive control, showed a mode fluorescence intensity of channel 60 as adjusted and gp 160 positive cells were counted at $81.7 \%$ of the sample cells (Fig. $1 \mathrm{~B}$ ). In this control the tumor marker gp 160 exhibited Gaussian distribution with a sharp peak.

Specimens were measured with the same sensitivity to fluorescence as the positive and the negative controls. The results are shown in Tables $1 \mathrm{~A}$ and $1 \mathrm{~B}$.

Among the carcinomas judged positive by flow cytometry, two different labeling patterns were observed. Cultured tumor cells showed uniformly intense staining (Fig. $1 \mathrm{~B}$ ), while nine tumors......five lung cancers, three stomach cancers and an ovarian cancer $\cdots \cdot$... showed a wide spectrum of fluorescence intensity, from low channel to high channel, without a sharp peak (Fig. $2 \mathrm{C}$ and $2 \mathrm{D}$ ).

In mesothelial cells and gp 160 negative cases, fluorescence was distributed only in low channels with a high peak, even when the gate was narrowed to the range only of large cells, which were assumed to be cancer cells (Fig. 3).

Comparison of the positive rate by cytometry and by cytology

Some samples without gp 160-positive cells showed positive fluorescence. When the data of flow cytometry and cytological diagnosis were compared, five out of 15 cytologically malignant specimens showed gp 160 positive in more than $70 \%$ of the cells, another five out of 15 cytologically malignant specimens showed gp 160 positive in $50 \%$ to $70 \%$ of the cells, one of two cytologically borderline specimens showed $40 \%-50 \%$ of the cells positive for gp 160, and in five out of six cytologically nonmalignant specimens, gp-160 positive cells were 

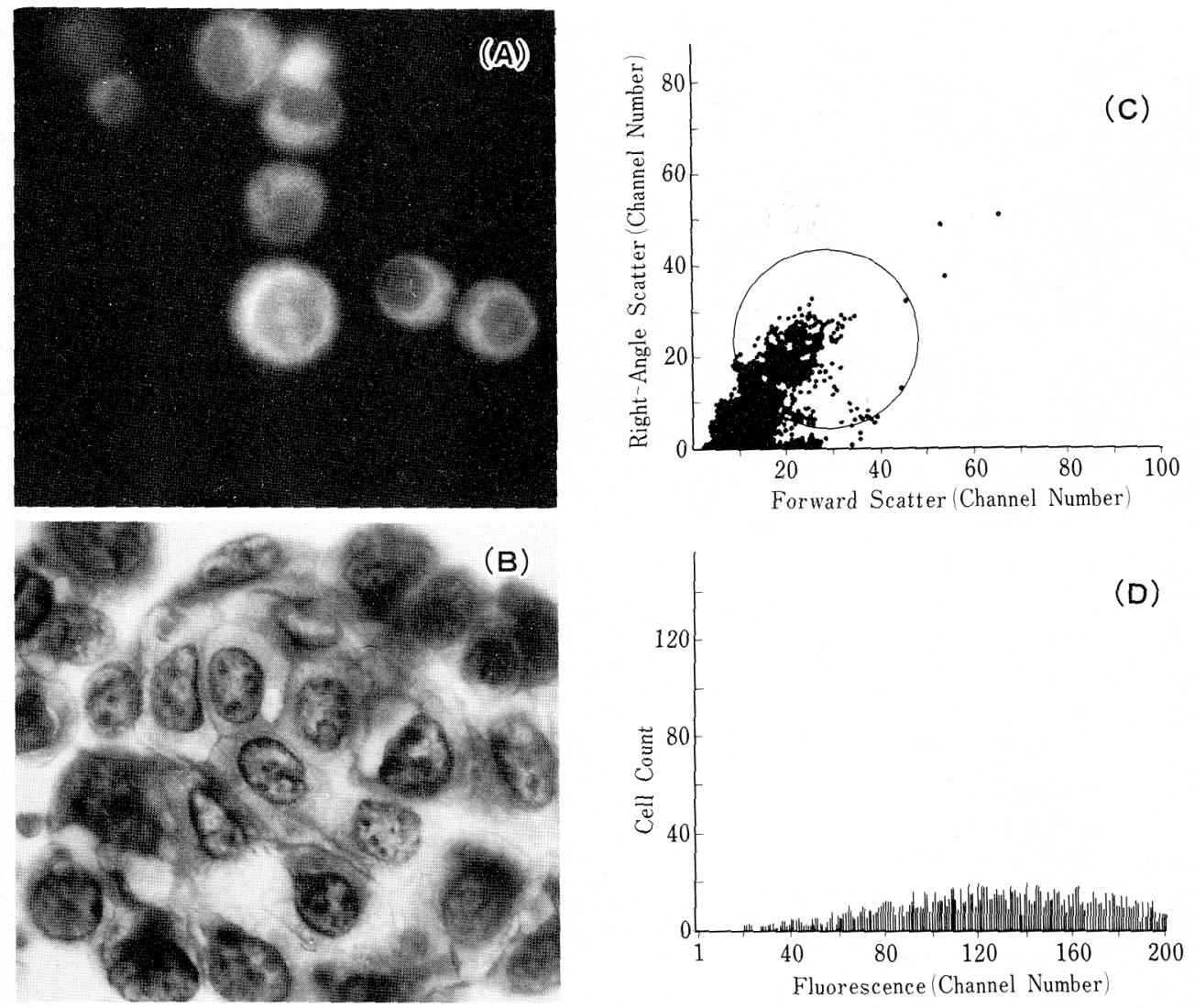

Fig. 2 A pleural effusion of adenocarcinoma of the lung (Case 1). 5 E 8-FITC immunofluorescence reaction (A): Papanicolaou's staining, $\times 190$ (B) ; flow cytometry of forward light scatter in $\mathrm{X}$-axis and $90^{\circ}$ scatter in $\mathrm{Y}$ axis (C) ; fluorescence intensity of cells reacted with $5 \mathrm{E} 8$ (circled in C) (D)

counted at less than $40 \%$. In body fluid specimens with lung cancer or stomach cancer cells, cytologically malignant specimens showed a gp 160 positive rate of more than $50 \%$ and a wide fluorescent distribution pattern (8/8).

\section{Discussion}

Immunofluorescent staining with the monoclonal antibody $5 \mathrm{E} 8$ followed by flow cytometry analysis detected gp 160 in body fluid specimens from patients with lung cancer, stomach cancer and ovarian cancer. Many cases of gp 160-positive tumor cells in body fluids showed varying degrees of stain intensity without a sharp peak and thus differed from the cultured tumor cells, which maintained a uniformly expressed gp 160. Such specimens might contain some cells other than tumor cells but still show a wide range of fluorescence intensity. These results are similar to those of image-analysis studies on the distribution of progesterone receptors and estrogen receptors in breast carcinomas ${ }^{9,10)}$.

The cellular mechanism responsible for heterogeneous gp 160 staining reactions is not known 



Fig. 3 Ascites of adenocarcinoma of the breast (case 16). Papanicolaou's staining, $\times 190$ (A) ; flow cytometry of forward light scatter in $\mathrm{X}$-axis and $90^{\circ}$ scatter in $\mathrm{Y}$ axis, narrower gate than cases in Figs. 1 and 2, (B) ; fluorescence intensity of cells reacted with $5 \mathrm{E} 8$ (circled in $\mathrm{B}$ ) (C) at the present time. Staining heterogeneity could be explained by the existence of varying levels of expression of the genes coding for gp 160, rather than by a complete loss of the gene. Further studies are necessary to elucidate the mechanism responsible for the variability in gp 160 expression.

Setting an arbitrarily dividing line between positive and negative populations is not desirable for practical use because some non-malignant cells show nonspecific fluorescence above channel 40. One resolution of this problem is to compare data for the same specimen reacted with both non-immune mouse IgG and the monoclonal antibody in order to make a better estimation of the positive rate. After the setting of a match range for the two histograms, the negative histogram (tumor cells stained with non-immune mouse IgG) is subtracted channel by channel from the positive histogram (anti gp 160 antibody). This allows dimly stained cells which would be disregarded in the arbitrary line method to be counted as positive ${ }^{2,4)}$. However, in the present study we could not compare with the negative control because the amount of each specimen was insufficient to stain it with non-immune mouse IgG.

More than $50 \%$ of the cells in the cytologically positive specimens with lung cancer or stomach cancer (8/8) were estimated as gp-160 positive by flow cytometry using the monoclonal antibody $5 \mathrm{E} 8$. Therefore, $5 \mathrm{E} 8$ may be useful in detecting lung cancer or stomach cancer cells in body fluids, although further study is necessary to put this technique to practical use for cancer screening.

\section{Acknowledgements.}

We are grateful to Dr. M. Naylor (MD Anderson Cancer Center, Science Park, U.S.A.) for generous advice. 


\section{要 約}

モノクローナル抗体 $5 \mathrm{E} 8$ を使用して, フローサイトメーター による体腔液中の腫瘍関連抗原 $\mathrm{gp} 160$ 陽性腫瘍細胞の検出を試 みた。陰性対照としてのリンパ球はチャンネル 10 に蛍光ピーク があり，95\%の細胞がチャンネル 40 以下であった.チャンネル 40 より蛍光強度の弱い細胞は $\mathrm{gp} 160$ 陰性とし, チャンネル 40 よ り蛍光強度の高い細胞を $\mathrm{gp} 160$ 陽性とした。陽性対照としての 肺の大細胞癌由来の培養細胞株 C-1509 の蛍光ピークをチャンネ ル 60 に感度調整したとき, gp 160 陽性細胞は 81.7\% であった。 肺癌および胃癌患者からの細胞診陽性体腔液検体では, 全例で $50 \%$ 以上の細胞が gp 160 陽性で広範な蛍光強度分布を示した (8/8).フローサイトメトリーによる体腔液中の肺癌または胃癌 細胞の検出にモノクローナル抗体 $5 \mathrm{E} 8$ は使用可能と考えられ た。

\section{References}

1) Johnson, T.S., Katz, R.L. and Pershouse, M. : Flowcytometric applications in cytopathology, Anal. Quant. Cytol. Histol., 10:423 458, 1988.

2) Schroff, R.W., Woodhouse, C.S., Foon, K.A. et al. : Intratumor localization of monoclonal antibody in patients with melanoma treated with antibody to a 250,000-dalton melanoma-associated antigen, J. Natl. Cancer Inst., $74: 299 \sim 306,1985$.

3) Jacobberger, J.W., Folgleman, D. and Lehman, J.M. : Analysis of intracellular antigens by flow cytometry, Cytometry, $7: 356 \sim 364,1986$.
4) Berd, D., Meenhard, H., Koprowski, H. et al. : Flow cytometric determination of the frequency and heterogeneity of expression of human melanoma-associated antigens, Cancer Res., 49 : 6840 6844, 1989.

5) Remvikos, Y., Laurent-Pug, P., Salmon, R.J. et al. : Simultaneous monitoring of p53 protein and DNA content of colorectal adenocarcinomas by flow cytometry, Int. J. Cancer, 45: 450 456, 1990.

6) Saji, S., Zylstra, S., Schepart, B.S. et al. : Monoclonal antibodies specific for two different histological types of human lung carcinoma, Hybridoma, $3: 119 \sim 129$, 1984.

7) Zylstra, S., Chen, F.A., Ghosh, S.K. et al. : Membrane -associated glycoprotein (gp160) identified on human lung tumors by a monoclonal antibody, Cancer Res., 46: 6446 6451, 1986.

8) Chen, F.A., Repasky, E.A., Takita, H. et al. : Cell surface glycoprotein associated with human lung tumors that is similar to but distinct from the epidermal growth factor receptor, Cancer Res., 49: 3642 3649, 1989.

9) Kommoss, F, Bibbo, M., Colley, M. et al. : Assessment of hormone receptors in breast carcinoma by immunocytochemistry and image analysis. I, Progesterone receptors, Analyt. Quant. Cytol. Histol., 11 : 298 306, 1989.

10) Colley, M., Kommoss, F., Bibbo, M. et al. : Assess ment of hormone receptors in breast carcinoma by immunocytochemistry and image analysis. II, Estrogen receptors, Analyt. Quant. Cytol. Histol., $11: 307 \sim 314,1989$. 